DOI: 10.14526/2070-4798-2020-15-2-71-78

\title{
Modern forms of teaching at a higher educational establishment by the example of "Physical culture elective courses" discipline in Nordic walking specialization
}

\author{
Svetlana $V$. Nageykina* \\ State University of Land use Planning and Control \\ Moscow, Russia \\ ORCID: oooo-ooo1-7305-9546,sveti-20oo@yandex.ru*
}

\begin{abstract}
Modern society develops in diversity and in interaction with material, spiritual and social phenomena in education. Modern concept of transformation at educational establishments demands real physical culture and sport problems solution, as the base of students' health preservation and strengthening. On the basis of scientific achievements the program of physical culture development transformation is realized and a healthy way of life among students of Russia is formed. The main aim of physical culture and sport elective course transformation at educational establishments is more popular and demanded kinds of motor activity for students introduction. Materials and Research methods. The following research methods were used: Information sources analysis and summarizing, testing, research results statistical handling. 28 students of the $1^{\text {st }}$ and the $2^{\text {nd }}$ courses of Land Management State University, Russia took part in the research. Students from the control group trained according to the traditional program. Students from the experimental group were offered the lessons with Nordic walking inclusion in the elective course. The methodology of Nordic walking realization included health-improving orientation. Preparatory part was $10 \%$ of the lesson general duration. General and special warming-up was held including general developing exercises of local and general influence on muscles. The main part of the lesson (75\%) included special training for the distance overcoming. The main criterion of physical loads training influences correction were pulse indices. For the effectiveness of the experimental methodology substantiation we chose three exercises: body lifting from dorsal position, arms bending in prone position, squats. The results estimation was in points, created taking into account physical condition of medical group students. Results. On the basis of normative indices according to point scale we created detailed point scale of medical group students' physical conditions estimation. The examined indices of physical readiness in special group students from CG and EG had the tendency of improvement, but in EG the results were more valid, than in CG, as the increase was $28,71 \%$, in CG only $7,9 \%$. Thus, systematic use of special exercises, directed toward physical qualities development, taking into account the specificity of Nordic walking, led to students' physical readiness improvement. Conclusion. It should be taken into account that low loads don't increase the effectiveness of physiological abilities of an organism and their general physical working capacity. Nordic walking is a unique kind of physical-sports activity. It helps to define the level of physical loads and increase them constantly without any harm to an organism. Systematic Nordic walking trainings, in particular of health-improving orientation, in case of their rational organization help to preserve high level of physical working capacity, tone up nervous system and regulate psychic state and increase functional abilities of cardiovascular system and respiratory function. An important component of Nordic walking physical load is metabolic processes of an organism activation and regulation. Physical culture and sport elective course with Nordic walking realization helps to realize individual approach and education differentiation successfully.
\end{abstract}

Keywords: Nordic walking, methodology, students, medical group, physical load, structure of the lesson.

For citation: Svetlana V. Nageykina*. Modern forms of teaching at a higher educational establishment by the example of "Physical culture elective courses" discipline in Nordic walking specialization. Russian Journal of Physical Education and Sport. 2020; 15(2): 58-63. DOI: 10.14526/2070-4798-2020-15-2-71-78 


\section{INTRODUCTION}

The level of a person's organism functioning comfort is closely connected with the necessary level of motor activity formation in a modern technological society and is an urgent problem. It is considered by many specialists $[1,2,4,5,9]$. Specialists in physical culture and sport study the effectiveness of innovative approaches realization of morpho-functional status change and effective sources of muscle activity energy supply formation in people. They go in for different kinds of sport $[5,6,7,8,12,13]$.Specialists of higher education are interested in the questions of social competence formation in students and the effectiveness of adaption improvement among the future specialists to the conditions of professional activity $[11,13]$.

In the Federal standard of higher education key moments of necessary level of students' competency are underlined. In this connection it is urgent to broaden the abilities of physical culture and sport elective courses, as the base for new kinds of physical-sports activity introduction into the life of population.

Physical culture and sport elective courses should provide the need formation for a healthy life style among students. They help to develop the skills and abilities, increase physical and functional readiness and adaptation in extreme and stress situations of a modern person's life.

Elective courses opportunities broadening is connected, first of all, with the tendency of different health problems level increase in students [11]. Specialists are interested in physical health of the future specialists in the sphere of physical culture and sport. They connect it with the need decrease for physical culture in terms of students' mental work increase.

The authors also revealed connection between motor activity and psychic state of students, for example, at medical higher educational establishments. They mentioned that students' cognitive and psychomotor indices depend on physical culture and sport means use $[1,2,4,5]$.

Taking into account important role of physical culture and sport in modern society as an integral part of social life at all levels of students' life, the first place takes personality's physical culture formation. In this connection the problem of new means introduction, directed toward independent lessons effectiveness increase, becomes urgent. Nordic walking became the part of students' life as an available and simple means. It doesn't demand expensive equipment.

Nordic walking is characterized as one of the kinds of cyclic exercises, fulfilled using special sticks for all groups of muscles inclusion into work.

Thus, the urgency of the presented problem is in experimental methodology creation for students' physical upbringing realization through Nordic walking lessons.

The main advantage of this kind of motor activity is the simplicity of physical load regulation according to intensity and duration. At the same time, oxygen consumption increases several times in comparison with static state, however, oxygen debt is minimal. Cardiovascular system trains and manages to provide organism with oxygen. We see $80 \%$ of muscles activity in terms of energy expenditure till $700 \mathrm{kkal}$.

The aim of this research work was to create and realize experimental methodology of students complex physical training by means of Nordic walking.

\section{MATERIALS AND METHODS}

The following research methods were used in the research: information sources analysis and summarizing, testing, research results statistical handling. 28 students of the 1st and the 2nd courses of the Land Management State University, Russia took part in the research. One control group and one experimental group were formed, each group included 14 people. Students from the control group trained according to the traditional program. Students from the experimental group were offered the lessons with Nordic walking inclusion in terms of the elective course. The methodology of Nordic walking realization included therapeutic and healthimproving orientation. Therapeutic orientation of sports walking use included planning the volume and intensity of Nordic walking, taking into account the level of physical readiness. Nordic walking lessons were held according to generally adopted system of lessons organization. The lessons had 
preparatory, main and the final parts.

Preparatory part was $10 \%$ of general duration of the lesson. General and special warmingup was held including general developing exercises of local and general influence on muscles. The main part of the lesson (75\%) included special training for the distance overcoming, taking into consideration individual characteristics of students.

The main criterion of physical loads training influences correction was pulse indices. The main part of the lesson on Nordic walking realization had aerobic regimen. For example, the first variant of aerobic training is $5^{-10} \mathrm{~min}$ distance overcoming with active rest during 5-10 minutes in terms of HR till 110 beats/min. Maximum repetition for one lesson was till 2 times. Maximal duration if the first variant of training use was 2-3 months. During the main part of the lesson we used the exercises of a directed influence on the body parts, taking into account the principles of exercises construction, such as: from simple to complicated, from top to bottom and to the parts of the body and for the whole body. Great attention was paid to the exercises of local influence. The initial level of students' physical fitness influenced the choice of means for the training complex of special exercises of different orientation according to biomechanical characteristics. For endurance development we used set distance overcoming, taking into account $\mathrm{HR}$ indices in moderate and training zones of intensity. The exercises for strength development were included additionally at the beginning and at the end of the main part of the lesson using weight. For example, hand power development was realized with the help of small weight (heavy stick). Physical qualities development was realized using specific exercises, similar to biomechanical characteristics of Nordic walking. For students' quickness development we used the exercises for short distances from 15 to 30 meters with small intensity rest till one minute, with the amount of repetitions till 10 times. During the final part of the lesson there was gradual physical load decrease till the initial level. The exercises for relaxation and stretching were used.

For the effectiveness of the experimental methodology substantiation we chose three exercises: body lifting from dorsal position, arms bending in prone position, squats. All testing exercises were fulfilled within one minute. The results estimation was held in points, created taking into account physical condition of medical group students.

Table 1 presents the created scale of the results evaluation in test exercises of students before and after the experiment.

Table 1 - Evaluation scale of physical condition testing in students of special medical group

\begin{tabular}{|c|c|c|c|c|c|c|}
\hline \multirow{2}{*}{ Testing exercises } & \multirow{2}{*}{ Orientation } & \multicolumn{5}{|c|}{ Evaluation scale (point) } \\
\hline & & 1 & 2 & 3 & 4 & 5 \\
\hline $\begin{array}{l}\text { Body lifting from dorsal } \\
\text { position (quantity) }\end{array}$ & $\begin{array}{c}\text { Power oriented abilities of } \\
\text { prelum } \\
\text { determination }\end{array}$ & 25 & 35 & 40 & 45 & 50 \\
\hline Squats (quantity) & $\begin{array}{l}\text { Power oriented abilities of } \\
\text { lower extremities muscles }\end{array}$ & 20 & 25 & 30 & 35 & 40 \\
\hline $\begin{array}{l}\text { Arms bending in prone } \\
\text { position (quantity) }\end{array}$ & $\begin{array}{l}\text { Power oriented abilities of } \\
\text { the whole body }\end{array}$ & 5 & 7 & 9 & 12 & 15 \\
\hline
\end{tabular}

\section{RESULTS AND DISCUSSION}

In order to substantiate the effectiveness of the Nordic walking methodology in the special medical group students we used the results in three testing exercises: body lifting from dorsal position; arms bending in prone position; squats. All testing exercises were fulfilled within one minute, adopted as the credit demand of physical culture and sport elective course. For the evaluation we used point scale, presented in table 1 .

On the basis of normative indices according to point scale we created detailed point scale of 
physical conditions estimation among in students of special medical group.
Detailed point scale of students' physical readiness estimation is presented in table 2.

Table 2 - Detailed point scale of physical conditions estimation in students of special medical group

\begin{tabular}{|c|c|c|c|c|c|}
\hline \multicolumn{2}{|c|}{ Body lifting } & \multicolumn{2}{|c|}{ Squats } & \multicolumn{2}{|c|}{ Arms bending } \\
\hline Quantity & Mark in points & Quantity & Mark in points & Quantity & $\begin{array}{c}\text { Mark in } \\
\text { points }\end{array}$ \\
\hline 25 and less & 1 & 20 and less & 1 & 5 and less & 1 \\
\hline 26 & 1,1 & & & & \\
\hline 27 & 1,2 & 21 & 1,2 & & \\
\hline 28 & 1,3 & & & & \\
\hline 29 & 1,4 & 22 & 1,4 & & \\
\hline 30 & 1,5 & & & 6 & 1,5 \\
\hline 31 & 1,6 & 23 & 1,6 & & \\
\hline 32 & 1,7 & & & & \\
\hline 33 & 1,8 & 24 & 1,8 & & \\
\hline 34 & 1,9 & & & & \\
\hline 35 & 2 & 25 & 2 & 7 & 2 \\
\hline 36 & 2,2 & 26 & 2,2 & & \\
\hline 37 & 2,4 & 27 & 2,4 & 8 & 2,5 \\
\hline 38 & 2,6 & 28 & 2,6 & & \\
\hline 39 & 2,8 & 29 & 2,8 & & \\
\hline 40 & 3 & 30 & 3 & 9 & 3 \\
\hline 41 & 3,2 & 31 & 3,2 & & \\
\hline 42 & 3,4 & 32 & 3,4 & 10 & 3,33 \\
\hline 43 & 3,6 & 33 & 3,6 & 11 & 3,66 \\
\hline 44 & 3,8 & 34 & 3,8 & & \\
\hline 45 & 4 & 35 & 4 & 12 & 4 \\
\hline 46 & 4,2 & 36 & 4,2 & & \\
\hline 47 & 4,4 & 37 & 4,4 & 13 & 4,33 \\
\hline 48 & 4,6 & 38 & 4,6 & 14 & 4,66 \\
\hline 49 & 4,8 & 39 & 4,8 & & \\
\hline 50 and more & 5 & 40 and more & 5 & 15 and more & 5 \\
\hline
\end{tabular}

Physical readiness study was held in September and after the experimental methodology realization in December.

The received results are presented in table 3.

Table 3 - The results of testing physical readiness of students from special medical group before and after the experiment

\begin{tabular}{|c|c|c|c|c|c|c|}
\hline \multirow{2}{*}{$\begin{array}{c}\text { The } \\
\text { group }\end{array}$} & $\begin{array}{c}\text { Stages of the } \\
\text { research }\end{array}$ & $\begin{array}{c}\text { Body lifting } \\
\text { quantity/ } \\
\text { point }\end{array}$ & $\begin{array}{c}\text { Squats } \\
\text { quantity / } \\
\text { point }\end{array}$ & $\begin{array}{c}\text { Arms bending } \\
\text { quantity / } \\
\text { point }\end{array}$ & $\begin{array}{c}\text { Sum of } \\
\text { points }\end{array}$ & Increase \\
\hline \multirow{2}{*}{ CG } & September & $28 / 1,3$ & $37 / 4,4$ & $11 / 3,66$ & 9,36 & $7,9 \%$ \\
\cline { 2 - 6 } & December & $30 / 1,5$ & $38 / 4,6$ & $12 / 4,0$ & 10,10 & \multirow{2}{*}{10,10} \\
\hline \multirow{2}{*}{ EG } & September & $30 / 1,5$ & $38 / 4,6$ & $10 / 3,3$ & \multirow{2}{*}{$28,71 \%$} \\
\cline { 2 - 6 } & December & $40 / 3,0$ & $45 / 5,0$ & $15 / 5,0$ & 13,0 & \\
\hline
\end{tabular}


The studied indices of students physical readiness from special medical group of $\mathrm{CG}$ and EG had the tendency for improvement, but in the EG the indices were more valid, the increase was $28,71 \%$, in CG the increase was only $7,9 \%$.

Thus, systematic use of special exercises, directed toward physical qualities development, taking into account the specificity of Nordic walking, leads to physical condition improvement in students of medical group.

\section{CONCLUSION}

Specialists in the sphere of physical culture and sport and also sports doctors recommend to train own organism during the whole life, regardless of motor activity. It should be taken into account that low loads don't increase the effectiveness of an organism physiological abilities and their general physical working capacity. Nordic walking is a unique kind of physical-sports activity. It helps to define the level of physical loads and increase them constantly without any harm to an organism. Systematic Nordic walking trainings, in particular of health-improving orientation, in case of their rational organization help to preserve high level of physical working capacity, tone up nervous system and regulate psychic state and increase functional abilities of cardiovascular system and respiratory function. An important component of Nordic walking physical load is metabolic processes of an organism activation and regulation. Physical culture and sport elective course with Nordic walking realization helps to realize individual approach and education differentiation successfully. It should be noted that Nordic walking is soft. It involves organism of people, who train into physical loads owing to gradual increase of endurance and tiredness resistance.

\section{REFERENCES}

1. Bulanova E.V., Osipova V.G., Korshunova L.A., Lebedeva E.A. Different means of physical culture influence on cognitive and psycho-motor indices of medical University students. Pedagogiko-psihologicheskie I medikobiologicheskie problemy fizicheskoj kul'tury I sporta = Russian Journal of Physical Education and Sport. 2019; 14(2): 38-42. DOI: 10.14526/20704798-2019-14-2-38-42 [In Russ., In Engl.]
2. Baronenko V.A. Motor activity is the leading universal factor of life and bioprogress optimization (report 1). Valeologiya. 2003; 1: 7-14 [In Russ.].

3. Vanyushin Yu.S., Sitdikov F.G. Adaptation of cardiac activity of teenagers to the increasing power load. Fiziologiya cheloveka. 2001; 27(2): 91-97 [In Russ.].

4. Gavronina G.A., Kuznetsova Z.M. Dynamics of physical readiness among female students, who go in for physical culture according to different educational programs. Teoriya I praktika fizicheskoj kul'tury $=$ Theory and practice of physical culture. 2008; 11: 83-86 [In Russ., In Engl.].

5. Gavronina G.A., Gorbunov N.P. The peculiarities of experimental program of physical upbringing among students of special medical group. Sportivno-orientirovannaya Sistema fizicheskogo vospitaniya - novaya pedagogicheskaya tehnologiya XXI veka. Sbornik materialov vserossijskoj nauchno-prakticheskoj konferencii (5-7 aprelya 2007g., g. Perm') [Sports-oriented system of physical upbringing is a new pedagogical technology of the XXI century. Collection of materials of All-Russian scientificpractical conference (April, 5-7, 2007, Perm)]. Perm. 2007: 56-59 [In Russ.].

6. Gibadullin I.G., Anisimova A.Yu., Ryabov M.E., Melnikov Yu.A. Theoretical and practical aspects of students' physical health formation at technical higher educational establishments. Pedagogiko-psihologicheskie I medico-biologicheskie problemy fizicheskoj kul'tury I sporta $=$ Russian Journal of Physical Education and Sport. 2019; 14(3): 73-79. DOI: 10.14526/20704798-2019-59-64 [In Russ., In Engl.]

7. Gizatullina Ch.A., Mutaeva I.Sh. The ways of sprinters' training individualization on the basis of taking into account typological characteristics of blood circulation. Pedagogikopsihologicheskie I mediko-biologicheskie problemy fizicheskoj kul'tury I sporta = Pedagogicopsychological and medico-biological problems of physical culture and sport. 2012; 3(24): 11-119. URL:http://kamgifk.ru/magazin/journal.htm [In Russ., In Engl.]

8. Grankin N.A., Kuznetsova Z.M. The indices of functional state and reserve capacities of an organism among cadets-weightlifters. Pedagogikopsihologicheskie I mediko-biologicheskie problemy fizicheskoj kul'tury I sporta = Pedagogicopsychological and medico-biological problems of physical culture and sport. 2017; 12(3): 58-67. DOI: 10.14526/03_2017_232 [In Russ., In Engl.].

9. Kozhevnikova N.G. The role of risk factors of life style in students' sickness rate formation. Zemskij doktor. 2011; 6: 13-17 [In Russ.]. 10. Church T.S., Earnest C.P., Morss G.M. 
Field testing of physiological responses associated with Nordic walking. Research Quarterly for Exercise and Sport. 2002; 73: 296-300.

11. Sharifullina S.R., Martynova V.A., Askhamov A.A., Zhestkova Yu.K. Differentiated approach to physical upbringing organization among the future teachers on the basis of morphofunctional indices. Teoriya I praktika fizicheskoj kul'tury $=$ Theory and practice of physical culture. 2017; 8: 18-20 [In Russ., In Engl.].

12. Petrov R.E., Mutaeva I.Sh., Ionov A.A. Aerobic threshold and potentialities of cardiac system determination and estimation among racing skiers (boys) on the basis of gradually-increasing ergometric load use. Pedagogiko-psihologicheskie I mediko-biologicheskie problemy fizicheskoj kul'tury I sporta = Russian Journal of Physical Education and Sport. 2018; 13(3): 137-146. DOI 10.14526/02_2018_326 [In Russ., In Engl.].

13. Sadykova G.S. Students' physical upbringing humanization at technical higher educational establishments. Kazanskij pedagogicheskij zhurnal. 2008; 5: 97-105 [In Russ.].

\section{Submitted: 29.12.2019}

\section{Author's information:}

Svetlana V. Nageykina - Lecturer, Associate Professor, State University of Land use Planning and Control, 105064, Russia, Moscow, Kazakova str., House 15, e-mail: sveti-200o@yandex.ru 